\title{
Androgenic effects of the antiprogestagen RMI 12,936
}

\author{
L. P. Bullock, P. D. Feil, C. Gupta, L. M. Demers and C. W. Bardin \\ Departments of Comparative Medicine, Medicine and Pathology, \\ The Milton S. Hershey Medical Center, The Pennsylvania State University, \\ Hershey, Pennsylvania 17033, U.S.A.
}

\begin{abstract}
Summary. RMI 12,936 (7 $\alpha$-methyl-17 $\beta$-hydroxy-androst-5-en-one) was tested for androgenic activity in mouse kidney and for antiprogestational activity in guinea-pig uterus. RMI 12,936 stimulated an increase in kidney weight and in the activity of the androgen-responsive renal enzymes, $\beta$-glucuronidase, alcohol dehydrogenase and arginase. RMI 12,936 was bound by the renal androgen receptor with a relative affinity approximately one-third that of testosterone. Although RMI 12,936 did not stimulate glycogen accumulation in guinea-pig endometrium in vivo, it was active in endometrial organ culture. When RMI 12,936 was combined with progesterone, glycogen accumulation in vitro was partly inhibited. RMI 12,936 was bound by the guinea-pig uterine progesterone receptor with a relative affinity of less than $1 \%$. It is concluded that RMI 12,936 is an androgenic steroid with antifertility actions and in-vitro antiglycogenic activity.
\end{abstract}

\section{Introduction}

The active components of most contraceptive agents are synthetic oestrogens and progestagens. While the effectiveness of these compounds is unquestioned, deleterious effects have been ascribed to their extended use (Kay et al., 1974) and new agents are continually being sought for fertility control. The fact that progesterone is essential for pregnancy maintenance spurred the search for a suitable antiprogestagen which could be used as a contraceptive. Kendle $(1975,1976)$ has studied a new synthetic steroid (7 $\alpha$-methyl-17 $\beta$-hydroxy-androst-5-en-3-one; RMI 12,936), which had antiprogestational activity and was effective as an infertility agent in the rat. Because this steroid was an androstane derivative, it seemed pertinent to compare its activity with that of androgens as well as progestagens in biological and receptor binding assays.

\section{Materials and Methods}

Reagents. Phenolphthalein glucuronic acid, phenolphthalein standard, 1-phenol-1,2-propanedione2-oxime and progesterone were obtained from Sigma. Tris (buffer grade) and sucrose (special density gradient grade) were obtained from Mann Research Laboratories. Trowell's T8 culture medium was purchased from Grand Island Biological Company. $\left[1,2-{ }^{3} \mathrm{H}\right]$ Testosterone (sp. act. $58 \mathrm{Ci} / \mathrm{mmol}$ ), $\left[1,2-{ }^{3} \mathrm{H}\right]$ progesterone (sp. act. $58 \mathrm{Ci} / \mathrm{mmol}$ ) and Liquiflor were obtained from New England Nuclear Corporation. Testosterone was obtained from Steraloids and RMI 12,936 was a gift from Merrell National Laboratories (Cincinnati, Ohio). All other chemicals were reagent grade.

Animals. C57BL/6J male mice, 6-8 weeks old, were purchased from Jackson Laboratories. Androgen-insensitive $\mathrm{t} \mathrm{fm} / \mathrm{y}$ mice were from the HMC line maintained at the Milton S. Hershey Medical Center. For the studies in vivo, mice were castrated under ether anaesthesia 3 weeks before the start of steroid treatment. Steroids were administered subcutaneously in $10 \%$ ethanol in sesame oil for 14 days at doses of $0.01-0.6 \mathrm{mg} / \mathrm{day}$. Mice were killed by cervical dislocation $24 \mathrm{~h}$ after the last dose. For the studies in vitro, animals were castrated $18 \mathrm{~h}$ before they were killed.

Ovariectomized, female Dunkin-Hartley guinea-pigs were obtained from Camm Research Institute, Wayne, New Jersey. Diethylstilboestrol (DES, $20 \mu \mathrm{g} /$ day) was administered in sesame oil 
for 2 days, starting no sooner than 10 days after ovariectomy. For the studies in vivo, oestrogentreated guinea-pigs were injected intravenously with vehicle $(0.5 \mathrm{ml} 50 \%$ ethanol-saline $)$ or vehicle + steroid $(1 \mathrm{mg})$ and killed by cervical dislocation after $6 \mathrm{~h}$.

Kidney enzyme assays. Kidneys from each mouse were weighed, minced and homogenized in $2 \mathrm{ml} 0.02 \mathrm{M}$-imidazol buffer, $\mathrm{pH} \mathrm{7.4}$. Except as mentioned, each sample was assayed in duplicate. Arginase and alcohol dehydrogenase activities were determined on fresh preparations. The remaining homogenates were frozen $\left(-70^{\circ} \mathrm{C}\right)$ until assayed for $\beta$-glucuronidase activity. Arginase (EC 3.5.3.1) activity was determined in kidneys from individual mice by the rate of formation of urea from arginine as described by Schimke (1971) with minor modifications. Crude tissue extracts were not activated with $\mathrm{MnCl}_{2}$ before the start of the assay. Since the enzyme reaction was linear between 30 and $60 \mathrm{~min}$, samples were incubated for various periods depending upon the expected activity. The final coloured product was developed by incubating the urea-oxime mixture for $20 \mathrm{~min}$ at $120^{\circ} \mathrm{C}$ in an autoclave. Colour formation was linear during this time. Results are expressed as units/g wet tissue with 1 unit being that activity forming $1 \mathrm{mmol}$ urea/h.

Alcohol dehydrogenase (EC 1.1.1.1) was assayed as described by Brandt, Elliott \& Swank (1975). Equal aliquots of fresh kidney homogenates from all animals in a treatment group were pooled and centrifuged at about $106000 \mathrm{~g}$ for $1 \mathrm{~h}$. The resultant cytosol $(1 \mathrm{ml})$ was chromatographed on a Sephadex G-25 fine column $(1 \times 15 \mathrm{~cm})$ and the protein eluting in $1 \mathrm{ml}$ of void volume was used for assay. The reaction was started by the addition of ethanol and followed by measuring $\mathrm{NADH}_{2}$ formation in a Gilford Recording Spectrophotometer at $340 \mathrm{~nm}$. Background values were measured in samples without substrate. Each pooled sample was assayed in duplicate. Protein concentration in the void volume was determined. Results are expressed as units/mg protein with 1 unit being that activity forming $1 \mathrm{nmol} \mathrm{NADH}_{2} / \mathrm{min}$.

Kidney $\beta$-glucuronidase (EC 3.2.1.31) activity was measured in homogenates from individual mice by the method of Fishman (1967). Results are expressed as units/g wet kidney weight, 1 unit being the activity liberating $1 \mu \mathrm{g}$ phenolphthalein/h.

Androgen binding assays. Mouse kidney cytosol was prepared as described previously (Bullock \& Bardin, 1974). Tissues were minced and homogenized in 2 volumes $(w / v)$ of buffer A $(0.05 \mathrm{M}-$ Tris$\mathrm{HCl}, 0.01 \mathrm{~mm}-\mathrm{Na}_{2}$ EDTA, $10 \%$ glycerol (v/v), and $0.25 \mathrm{~mm}$-dithiothreitol, added fresh daily) $\mathrm{pH} 7 \cdot 4$ at $22^{\circ} \mathrm{C}$. Homogenates were centrifuged at $120000 \mathrm{~g}$ for $1 \mathrm{~h}$.

The analysis of androgen binding by centrifugation through $5-20 \%$ sucrose gradients has been described previously (Bullock \& Bardin, 1974). Cytosol was incubated with 2 nM- $\left[{ }^{3} \mathrm{H}\right]$ testosterone with or without a 100 -fold excess of RMI 12,936 or nonradioactive testosterone. Aliquots were then centrifuged through sucrose at $300000 \mathrm{~g}$ for $16 \mathrm{~h}$ before fractionation and counting of the gradient.

To determine the affinity of the androgen receptor for RMI 12,936, aliquots of cytosol were incubated with $2.6 \mathrm{nM}-\left[{ }^{3} \mathrm{H}\right]$ testosterone. Competing steroids, testosterone or RMI 12,936, were added simultaneously in molar ratios $(1: 1$ to $500: 1)$ of competitor: $\left[{ }^{3} \mathrm{H}\right]$ testosterone. Bound and free steroids were separated at $4^{\circ} \mathrm{C}$ on DEAE-filters (DE-81, Whatman, Inc., New Jersey) by a minor modification of the procedure by Santi, Sibley, Perriard, Tomkins \& Baxter (1973). The relative binding affinity of RMI 12,936 for the androgen receptor was calculated at the $50 \%$ competition level by the method of Korenman (1968). The bound-to-free ratio of $\left[{ }^{3} \mathrm{H}\right]$ testosterone at which the comparison was made was $0 \cdot 1$ (Rodbard, 1973).

Uterine glycogen assay. Guinea-pigs were killed $6 \mathrm{~h}$ after administration of steroid or vehicle, the uteri were excised and the endometrium was stripped and frozen on solid $\mathrm{CO}_{2}$. The glycogen content of each uterus was measured colorimetrically (Demers, Gabbe, Villee \& Greep, 1972) in triplicate and the average determined. The coefficient of variation for this assay was $10 \%$.

For the studies in vitro, uteri from DES-primed animals were removed and the endometrium was obtained for organ culture as previously described (Demers, Feil \& Bardin, 1977). Briefly, endometrial fragments from 6-8 guinea-pigs were pooled and apportioned equally into culture dishes containing Trowell's T8 medium. Various steroids were added to duplicate cultures and after $48 \mathrm{~h}$ a single glycogen determination was performed for each culture.

Progestagen binding assay. Guinea-pig uterine cytosol was prepared as described previously (Feil \& Bardin, 1975). Aliquots $(0.2 \mathrm{ml})$ of cytosol were incubated for $1 \mathrm{~h}$ with $3 \mathrm{nM}-\left[{ }^{3} \mathrm{H}\right]$ progesterone 
and increasing concentrations of competitor (500-fold range). Bound and free steroid were separated with dextran-coated charcoal and counted as previously reported (Feil, Glasser, Toft \& O'Malley, 1972). The relative binding affinity of the competitor for the receptor, compared to unlabelled progesterone, was calculated at the $50 \%$ competition level by the method of Korenman (1968). The bound-to-free ratio at which the comparison was made was 0.4 (Rodbard, 1973).

Other measurements. Protein was measured by the method of Lowry, Rosebrough, Farr \& Randall (1951) by using BSA as standard. For quantitation of radioactivity, $10 \mathrm{ml}$ scintillation fluid ( $42 \mathrm{ml}$ Liquiflor, $1000 \mathrm{ml}$ toluene) were added to samples from sucrose gradients; $10 \mathrm{ml}$ phosphor-T (42 $\mathrm{ml}$ Liquiflor, $330 \mathrm{ml}$ Triton X-100 and $670 \mathrm{ml}$ toluene) were added to vials containing DEAE filters. Samples were allowed to equilibrate in the dark for $4 \mathrm{~h}$ before counting in a Beckman LS-250 liquid scintillation counter (ambient temperature) with a ${ }^{3} \mathrm{H}$ efficiency of $35-38 \%$. Statistical evaluations were by 2-tailed Student's $t$ tests.

\section{Results}

\section{Effects of RMI 12,936 on the kidney and reproductive tract of male mice}

In-vivo studies. In the mouse, RMI 12,936 stimulated an androgenic response with a potency similar to that of testosterone. This dose-related response was evident as an increase in target organ weights (Table 1) and in the activity of several androgen-responsive renal enzymes (Table 2). As expected, testosterone administration had no effect on enzyme activity in androgen-insensitive $t \mathrm{fm} / \mathrm{y}$ mice (Table 2). In contrast, although RMI 12,936 did not alter the activity of $\beta$-glucuronidase or alcohol dehydrogenase, it was associated with an increase in arginase activity in these animals (Table 2). An even larger dose of RMI 12,936 ( $1.0 \mathrm{mg}$ for 14 days) again had no effect on $\beta$-glucuronidase or alcohol dehydrogenase activity in these mice, although arginase activity increased by $100 \%$ (data not shown).

Table 1. Response (as organ wet weight, $\mathrm{mg}$ ) of tissues of castrated mice to daily treatment with testosterone or RMI 12,936 for 14 days

\begin{tabular}{clccccc}
\hline \multirow{2}{*}{ Organ } & Steroid & None & 0.05 & $0 \cdot 1$ & 0.25 & 0.6 \\
\cline { 3 - 7 } & & & & \multicolumn{5}{c}{ Steroid dose (mg/day) } \\
\hline Kidney & Testosterone & $238 \pm 8$ & $273 \pm 28$ & $273 \pm 18$ & $307 \pm 22^{*}$ & $298 \pm 22$ \\
& RMI 12,936 & $238 \pm 8$ & $296 \pm 14 \dagger$ & $310 \pm 9 \dagger$ & $349 \pm 11 \dagger$ & $378 \pm 13 \dagger$ \\
Preputial & Testosterone & $24 \pm 3$ & $37 \pm 8$ & $42 \pm 5^{*}$ & $45 \pm 12$ & $43 \pm 3 \dagger$ \\
gland & RMI 12,936 & $24 \pm 3$ & $30 \pm 2$ & $36 \pm 3^{*}$ & $44 \pm 2 \dagger$ & $58 \pm 4 \dagger$ \\
Seminal & Testosterone & $19 \pm 3$ & $54 \pm 6 \dagger$ & $63 \pm 12 \dagger$ & $65 \pm 6 \dagger$ & $95 \pm 8 \dagger$ \\
vesicle & RMI 12,936 & $19 \pm 3$ & $62 \pm 6 \dagger$ & $67 \pm 6 \dagger$ & $95 \pm 6 \dagger$ & $100 \pm 7 \dagger$ \\
\hline
\end{tabular}

Values are means \pm s.e.m. for $4-5$ mice.

Significantly different from control value: ${ }^{*} P<0.05 ; \dagger P<0.01$.

In-vitro studies. The insensitivity of $t \mathrm{fm} / \mathrm{y}$ mice to some of the effects of RMI 12,936 suggested that its action on the kidney might be partly mediated by the androgen receptor. The ability of RMI 12,936 to inhibit androgen binding in mouse kidney cytosol was therefore examined. The addition of 100 -fold excess of RMI 12,936 completely abolished the binding of $\left[{ }^{3} \mathrm{H}\right]$ testosterone to an $8 \mathrm{~S}$ macromolecule (data not shown) that had previously been identified as the androgen receptor (Bullock \& Bardin, 1974). RMI 12,936 was bound by the androgen receptor with an affinity approximately one-third that of testosterone (Text-fig. 1).

\section{Effects of RMI 12,936 on the guinea-pig uterus}

In-vivo studies. Progesterone produced a $90 \%$ increase in glycogen accumulation in the endometrium of oestrogen-primed guinea-pigs ( 185 and $167 \mu \mathrm{g}$ glycogen/100 mg wet tissue) over that of 
Table 2. Response of kidney enzymes of castrated mice or intact $t f m / y$ mice to daily treatment with testosterone or RMI 12,936 for 14 days

\begin{tabular}{|c|c|c|c|c|c|c|c|}
\hline \multirow[b]{2}{*}{ Enzyme } & \multirow[b]{2}{*}{ Source } & \multirow[b]{2}{*}{ Steroid } & \multicolumn{5}{|c|}{ Steroid dose (mg/day) } \\
\hline & & & None & 0.05 & $0 \cdot 1$ & 0.25 & 0.6 \\
\hline$\beta$-Glucuronidase & $\begin{array}{l}\text { Castrated } \\
t f m / y\end{array}$ & $\begin{array}{l}\text { Testosterone } \\
\text { RMI } 12,936 \\
\text { Testosterone } \\
\text { RMI } 12,936\end{array}$ & $\begin{array}{l}1359 \pm 57 \\
1359 \pm 57 \\
1101 \pm 63 \\
1101 \pm 63\end{array}$ & $\begin{array}{c}1377 \pm 80 \\
- \\
-\end{array}$ & $\begin{array}{c}1595 \pm 126 \\
- \\
-\end{array}$ & $\begin{array}{c}2350 \pm 160 \dagger \\
3772 \pm 214 \dagger \\
906 \pm 81 \\
1087 \pm 76\end{array}$ & $\begin{array}{c}2665 \pm 72 \dagger \\
- \\
1004 \pm 130 \\
1150 \pm 55\end{array}$ \\
\hline $\begin{array}{l}\text { Alcohol } \\
\text { dehydrogenase }\end{array}$ & $\begin{array}{l}\text { Castrated } \\
t f m / y\end{array}$ & $\begin{array}{l}\text { Testosterone } \\
\text { RMI } 12,936 \\
\text { Testosterone } \\
\text { RMI } 12,936\end{array}$ & $\begin{array}{l}0.6 \\
0.6 \\
0.9 \\
0.9\end{array}$ & $\begin{array}{l}3 \cdot 4 \\
3 \cdot 6 \\
- \\
-\end{array}$ & $\begin{array}{l}7.0 \\
7.0 \\
- \\
-\end{array}$ & $\begin{array}{l}7 \cdot 6 \\
9 \cdot 0 \\
0 \cdot 8 \\
0 \cdot 9\end{array}$ & $\begin{array}{l}3.8 \\
7.0 \\
0.9 \\
0.6\end{array}$ \\
\hline Arginase & $\begin{array}{l}\text { Castrated } \\
t f m / y\end{array}$ & $\begin{array}{l}\text { Testosterone } \\
\text { RMI } 12,936 \\
\text { Testosterone } \\
\text { RMI } 12,936\end{array}$ & $\begin{array}{l}0.31 \pm 0.02 \\
0.31 \pm 0.02 \\
0.66 \pm 0.07 \\
0.66 \pm 0.07\end{array}$ & $\begin{array}{c}0.32 \pm 0.03 \\
0.37 \pm 0.04 \\
- \\
-\end{array}$ & $\begin{array}{c}0.23 \pm 0.02 \\
0.75 \pm 0.19^{*} \\
- \\
-\end{array}$ & $\begin{array}{l}0.22 \pm 0.02 \\
1.54 \pm 0.07 \dagger \\
0.59 \pm 0.04 \\
0.84 \pm 0.04^{*}\end{array}$ & $\begin{array}{l}0.86 \pm 0.23 \\
3.64 \pm 0.20 \dagger \\
0.62 \pm 0.07 \\
1.12 \pm 0.06 \dagger\end{array}$ \\
\hline
\end{tabular}

Values are mean \pm s.e.m. for 4-5 mice/group, and are expressed as $\mu \mathrm{g}$ phenolphthalein formed/h $\mathrm{g}$ tissue ${ }^{-1}$ for $\beta$-glucuronidase, nmol $\mathrm{NADH}_{2}$ formed $/ \mathrm{min} \mathrm{mg}$ protein ${ }^{-1}$ (pooled cytosol) for alcohol dehydrogenase, and mmol urea formed $/ \mathrm{h} \mathrm{g}$ tissue ${ }^{-1}$ for arginase.

Values significantly different from control: ${ }^{*} P<0.05 ; \dagger P<0.01$.

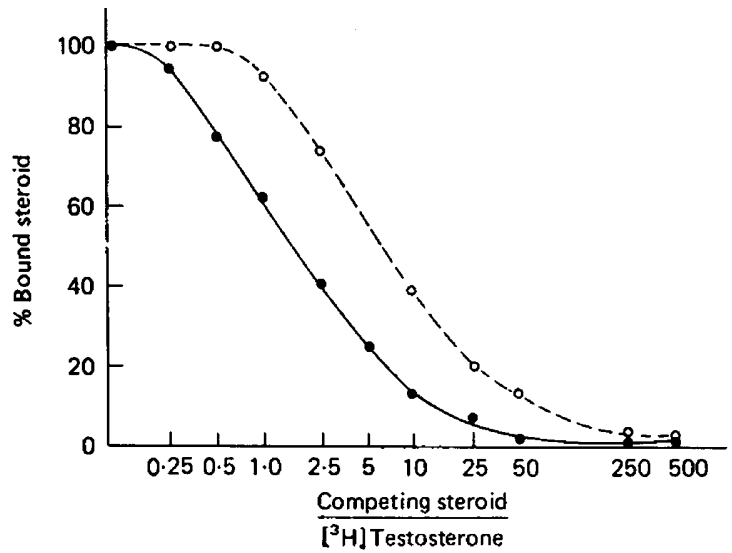

Text-fig. 1. Relative binding affinity of RMI 12,936 and testosterone to the androgen receptor in mouse kidney cytosol. $\left[{ }^{3} \mathrm{H}\right]$ Testosterone $(2.6 \mathrm{nM})$ and various amounts of testosterone $(\bullet)$ or RMI $12,936(0)$ were incubated with mouse kidney cytosol and assayed as described in 'Materials and Methods'.

control endometrium ( 95 and $89 \mu \mathrm{g}$ glycogen/100 mg wet weight), whereas RMI 12,936 was without effect (103, 76 and $90 \mu \mathrm{g}$ glycogen $/ 100 \mathrm{mg}$ wet weight).

In-vitro studies. The results of a typical experiment to examine the effects of progesterone and RMI 12,936 on endometrial glycogenesis in organ culture are shown in Text-fig. 2. In 4 experiments, the glycogen content in control cultures was $90 \pm 23$ (s.e.m.) $\mu \mathrm{g} / 100 \mathrm{mg}$ wet weight. With small doses $(0.2 \mu \mathrm{g})$, progesterone stimulated a $117 \%$ and $283 \%$ increase in glycogen content over control values while RMI 12,936 induced a rise of $226 \pm 43 \%$. Large doses of steroid ( $2 \mu \mathrm{g})$ produced increases of $356 \pm 73 \%$ and $283 \pm 85 \%$ over controls for progesterone and RMI 12,936, respectively. When RMI 12,936 and progesterone were present in the medium in a $1: 1$ ratio, glycogen accumulation was only $53 \pm 2 \%$ (s.e.m., $n=4$ ) that stimulated by progesterone alone. In a fifth experiment, no inhibition occurred. In other experiments in which the progesterone response was less than twice the control, inhibition by RMI 12,936 was not detected. At comparable doses, testosterone stimulated glycogen accumulation by $389 \pm 86 \%$ of the control value (s.e.m., $n=4$ ). In 2 experiments in which 


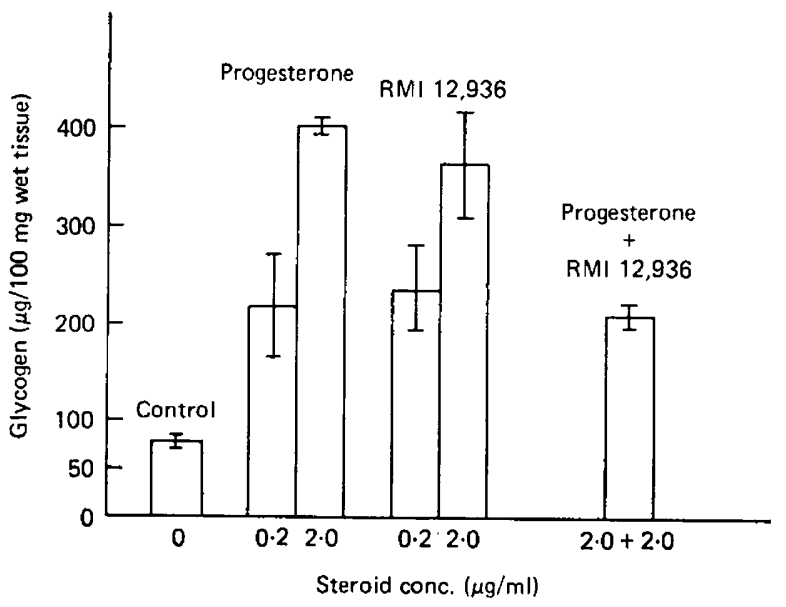

Text-fig. 2. Result of a typical experiment in which endometrial fragments from a pool of 7 oestrogentreated guinea-pigs were incubated for $48 \mathrm{~h}$ in the presence of the indicated concentrations of progesterone and RMI 12,936. Glycogen was determined colorimetrically as described in 'Materials and Methods'. Each column represents the mean of the 2 determinations which are indicated by the vertical bars.

the progesterone response was greater than twice the control, testosterone inhibited the response by 40 and $64 \%$.

In the progesterone receptor assay, the relative binding affinity of RMI 12,936 was less than $1 \%$ (progesterone $=100 \%$ ), and indicates that RMI 12,936 has a greater affinity for the androgen receptor of the mouse kidney than for the progesterone receptor of the guinea-pig uterus.

\section{Discussion}

Compounds which inhibit the action of progesterone on the uterus are of great interest because they could prevent implantation and interrupt pregnancy, but these compounds often have troublesome side effects. The antiprogestagen, RMI 12,936 and its isomer, $7 \alpha$-methyltestosterone, have been reported to be androgenic in the rat (Kendle, 1976; Grunwell, Benson, Johnston \& Petrow, 1976). Similar results were obtained in the present study when RMI 12,936 was assayed in male mouse accessory sex tissues and kidney. In the mouse, most responses induced by RMI 12,936 and testosterone were similar. However, not only was RMI 12,936 more potent than testosterone in stimulating arginase activity but the pattern of response was different: RMI 12,936 increased enzyme activity with all doses used, whereas testosterone produced a biphasic response in which low doses were associated with a decrease in enzyme activity followed by an increase as larger doses were given. This difference in the response induced by the two steroids was seen in 3 experiments. Kochakian (1945) observed a similar difference in response when 17 $\alpha$-methyltestosterone and testosterone were compared. While $17 \alpha$-methyltestosterone produced some kidney growth, it apparently had a more direct effect on arginase activity, resulting in an increase in specific activity at all doses used (Kochakian, 1945). By contrast, testosterone administration was associated with an initial decrease in specific activity which was ascribed to stimulation of kidney growth before a direct effect on enzyme activity had occurred (Kochakian, 1945).

Administration of RMI 12,936 but not testosterone was also associated with a slight increase in arginase activity in the androgen-insensitive $\mathrm{tfm} / \mathrm{y}$ mice. Oestradiol will also stimulate arginase activity in mouse kidney (Kochakian, Garber \& Bartlett, 1948) and RMI 12,936 has been reported to have some oestrogenic action (Kendle, 1975). Since $t \mathrm{fm} / y$ mice have intact renal oestrogen receptors (Bullock \& Bardin, 1975), it is possible that an oestrogenic effect could have caused the arginase response in these animals. 
Progesterone has a distinct effect on guinea-pig uterine glycogen metabolism which requires the concomitant action of insulin and involves RNA and polyamine synthesis (Demers et al., 1977; Feil, Pegg, Demers \& Bardin, 1977). This can be demonstrated in vivo and in vitro. While RMI 12,936 was without effects in vivo, it increased glycogen deposition and inhibited the normal response to progesterone when removed from circulatory influences and studied in organ cultures. It is not known whether these effects are related to the androgenic effects of RMI 12,936. The similar responses induced by testosterone suggest this possibility.

The molecular mechanisms by which RMI 12,936 exerts its androgenic and antiprogestational effects are not completely understood. Most stimulators or inhibitors of steroid action exert their effects by binding to their respective steroid receptors. The ability of RMI 12,936 to displace $\left[{ }^{3} \mathrm{H}\right]-$ testosterone binding in kidney cytosol at $4^{\circ} \mathrm{C}$ suggests that its androgenic effects are mediated directly via the androgen receptor. However, the inability of RMI 12,936 to compete for $\left[{ }^{3} \mathrm{H}\right]$ progesterone binding sites in either human (Kendle, 1975) or guinea-pig uterus (present study) suggests that, in the uterus, RMI 12,936 may act independently of the progesterone receptor or by way of a metabolite. RMI 12,936 inhibits progesterone synthesis in rat ovaries by acting as an alternative substrate for $\Delta^{5}$-3-ketosteroid isomerase with the subsequent production of $7 \alpha$-methyltestosterone (Kendle, 1976; Hardy, Kendle, Lawrie \& Omand, 1977). The latter steroid may be a competitive antagonist of the progesterone receptor (Kendle, 1976), but the metabolism of RMI 12,936 and the binding of its metabolites in relation to progesterone or other receptors in the guinea-pig uterus need to be studied.

This study was supported by USPHS Contract No. N01-HD-2-2730 and N01-HD-1-2228. L.P.B. is the recipient of an RCDA No. K04-HD-00137 from the National Institutes of Health. C.W.B. is the recipient of a Faculty Scholar award from the Josiah Macy, Jr Foundation. We thank Suzanne Ganse, Naomi R. Cole and Bethe Eppley for their able technical assistance and Marlene Brinser for typing the manuscript.

\section{References}

Brandt, E.J., Elliott, R.W. \& Swank, R.T. (1975) Defective lysosomal enzyme secretion in kidneys of Chediak-Higashi (beige) mice. J. Cell Biol. 67, 774-788.

Bullock, L.P. \& BardiN, C.W. (1974) Androgen receptors in mouse kidney: a study of male, female and androgen-insensitive (tfm/y) mice. Endocrinology 94, 746-756.

BullOCK, L.P. \& BARDIN, C.W. (1975) The presence of estrogen receptor in kidneys from normal and androgen-insensitive $\mathrm{tfm} / \mathrm{y}$ mice. Endocrinology 97 , 1106-1111.

Demers, L.M., FeIl, P.D. \& Bardin, C.W. (1977) Factors influencing steroid induction of endometrial glycogenesis in organ culture. N.Y. Acad. Sci. 286, 249-259.

Demers, L.M., Gabbe, S.G., Villee, C.A. \& Greep, R.O. (1972) The effect of insulin on human placental glycogenesis. Endocrinology 91, 270-275.

Feil, P.D. \& Bardin, C.W. (1975) Cytoplasmic and nuclear progesterone receptors in the guinea pig uterus. Endocrinology 97, 1398-1407.

Feil, P.D., Glasser, S.R., Toft, D.O. \& O'Malley, B.W. (1972) Progesterone binding in the mouse and rat uterus. Endocrinology 91, 738-746.

Feil, P.D., PegG, A.E., Demers, L.M. \& Bardin, C.W. (1977) Involvement of polyamines in the progestininduced stimulation of endometrial glycogen syn- thesis during organ culture. Biochem. Biophys. Res. Commun. 75, 1-6.

Fishman, W.H. (1967) Determination of $\beta$-glucuronidases. In Methods of Biochemical Analysis, Vol. 15, pp. 77-145. Ed. D. Glick. Interscience, New York.

Grunwell, J.F., Benson, H.D., Johnston, J.O. \& Petrow, V. (1976) Anti-progestational agents. The synthesis of 7-alkyl steroidal ketones with antiimplantational and antidecidual activity. Steroids 27, 759-771.

HaRdy, D.G., Kendle, K.E., Lawrie, M.R. \& OMand, H.E. (1977) The effect of RMI 12,936, a synthetic progestational steroid, on ovarian steroidogenesis in the rat. J. Reprod. Fert. 49, 231-235.

Kay, C.R., Crombie, D.L., Kuenssberg, E.V., Pinsent, R.J.F.H., RICHARD, B. \& SMITH, A. (1974) Oral Contraception Study. Pitman Publishing Co., New York.

KENDLE, K.E. (1975) Some biological properties of RMI 12,936, a new synthetic antiprogestational steroid. J. Reprod. Fert. 43, 505-513.

KENDLE, K.E. (1976) Effects of RMI 12,936, a synthetic antiprogestational steroid, in the rat. $J$. Reprod. Fert. 48, 159-166.

Kochakian, C.D. (1945) The effect of dose and nutritive state on kidney arginase after steroid stimulation. J. biol. Chem. 161, 115-125.

Kochakian, C.D., Garber, E.E. \& Bartlett, M.N. 
(1948) Effect of estrogen alone and in combination with testosterone on the body and organ weights and the arginase and phosphatases of the organs of the mouse. Am. J. Physiol. 155, 265-271.

KORENMAN, S.G. (1968) Radio-ligand binding assay of specific estrogens using a soluble uterine macromolecule. J. clin. Endocr. Metab. 28, 127-130.

LOWRY, O.H., Rosebrough, N.J., FARR, A.L. \& RANDALI, R.J. (1951) Protein measurement with the folin phenol reagent. J. biol. Chem. 193, 265-275.

RODBARD, D. (1973) Mathematics of hormone-receptor interaction. In Receptors for Reproductive Hormones, pp. 289-326. Eds B. W. O'Malley \& A. R. Means. Plenum Publishing Co., New York.

Santi, D.V., Sibley, C.H., Perriard, E.R., Tomkins, G.M. \& BAXTER, J.D. (1973) A filter assay for steroid hormone receptors. Biochemistry, N.Y. 12, 2412-2416.

Schimкe, R.T. (1971) Arginase (rat liver). In Methods in Enzymology, Vol. XVII, Part A, pp. 313-317. Eds H. Tabor \& C. W. Tabor. Academic Press, New York.

Received 23 February 1977 